\title{
Influencia de las fendas en la resistencia de la madera estructural
}

\section{The effect of fissures on the strength of structural timber}

\author{
M. Esteban $(*), F$. Arriaga(*), G. Íñiguez ${ }^{(* *)}$, I. Bobadilla(***), R. Mateo(**)
}

Recepción/Received: 21-V-2008

Aceptación/Accepted: 13-IV-2009

Publicado online/Online publishing: 24-III-2010

\section{RESUMEN}

Se han realizado mediciones detalladas de las fendas de secado en 28 piezas de madera de pino silvestre de gran escuadría. Se han propuesto diferentes parámetros para medir su magnitud en longitud, profundidad, grosor e inclinación, así como un índice de áreas en el plano medio de rasante (superficie eficaz respecto a superficie total). Se han relacionado los parámetros de fendas con resistencia a flexión, resistencia a cortante, módulo de elasticidad y energía de rotura obtenidos mediante ensayos mecánicos, teniendo en cuenta si la rotura se produce por flexión o por cortante. Todas las fendas observadas permiten clasificar las piezas como MEG según la norma UNE 56544. Se propone cuantificar las fendas mediante el índice de áreas y las propiedades mecánicas mediante la energía de rotura. El análisis realizado no muestra una relación significativa entre las fendas analizadas, los modos de rotura o las propiedades mecánicas.

Palabras clave: madera, propiedades mecánicas, caracterización, fendas de secado.

\section{SUMMARY}

Detailed measurements of drying fissures were carried out on 28 pieces of gross cross-section structural Scots pine timber. Different parameters have been proposed to measure their magnitude: length, depth, thickness and slope of grain, as well as an index of area in the neutral axis plane (ratio of effective to total surface). The parameters of fissures have been related to bending strength, shear strength, modulus of elasticity and rupture energy obtained from mechanical tests, considering whether rupture is due to bending or shear. All of the fissures observed allows to classify the pieces as MEG according to the UNE 56544 standard. To quantify the magnitude of fissures the index of areas is proposed, while mechanical properties can be quantified by rupture energy. Analysis of the results does not show any relation between the fissures analyzed and the mode of failure, their magnitude and mechanical properties.

Keywords: timber, mechanical properties, characterization, drying fissures.

\section{INTRODUCCIÓN}

La calidad de la madera para uso estructural se evalúa en función de la cantidad y tamaño de los defectos (nudos, fendas, desviación de la fibra, gemas, etc.) de

\section{INTRODUCTIÓN}

Structural timber grade is evaluated based on the quantity and size of defects (knots, fissures, slope of grain, wanes, etc.) according to the visual stress grading

(*) Universidad Politécnica de Madrid, ETSI Montes (Madrid, España).

(**) AITIM (Madrid, España).

(***) Universidad Politécnica de Madrid, EUIT Forestal (Madrid, España). 
acuerdo a las normas de clasificación visual. Es bien conocida la influencia de algunos defectos como los nudos o la desviación de la fibra, pero no sucede lo mismo con otros muy frecuentes y aparentemente alarmantes como las fendas.

Las normas con incidencia en España para la clasificación visual de la madera estructural en la Unión Europea son la DIN 4074 (Alemania) (1), BS 4978 (Gran Bretaña) (2), NF B 52001 (Francia) (3), INSTA 142 (Países Nórdicos) (4) y UNE 56544 (España) (5). Estas normas están desarrolladas generalmente para escuadrías comerciales que abarcan gruesos de 35 a $100 \mathrm{~mm}$ con un canto máximo de unos $300 \mathrm{~mm}$.

Una de las dificultades de aplicación de estas normas se encuentra en la limitación de las fendas de secado. La aparición de fendas es motivo de alarma, pero la realidad es que la norma de clasificación visual es muy tolerante en la aplicación de este criterio. El número de rechazos por fendas suele ser pequeño pero limita mucho las calidades superiores. Esto da pie a pensar que la influencia de las fendas en las propiedades mecánicas es relativamente pequeña. Este inconveniente se ha detectado en la normativa francesa, deduciendo la necesidad de modificar las especificaciones de la norma para su empleo en grandes escuadrías (6).

\subsection{Tipos de fendas}

Con carácter general se denomina fenda (según la norma UNE-EN 844-9) a toda separación de las fibras (raja o hendidura) en dirección longitudinal (7). Algunos tipos de fendas se manifiestan por una discontinuidad entre los anillos de crecimiento y se denominan de acebolladura. Existen diferentes tipos de fendas, normalmente atendiendo a su origen o forma:

- Fendas de secado: se forman durante el secado de la madera. Cuando la madera pierde humedad, la merma en dirección tangencial es mucho mayor que en la dirección radial (del orden del doble), dando lugar a tensiones internas que producen una separación de las fibras en forma de fendas.

- Fenda por rayo: fenda originada por un rayo.

- Fenda superficial: separación entre fibras que se presenta en una cara o canto sin extenderse al interior de la pieza y que se elimina fácilmente con un cepillado superficial.

- Fenda de heladura: fenda radial originada por la acción de la helada en la madera en pie, extendiéndose desde la albura hacia la médula con una longitud notable.

- Fenda de apeo: se originan durante el abatimiento del árbol y se manifiestan sobre el extremo grueso del fuste, extendiéndose longitudinalmente. rules. The influence of some defects such as knots or slope of grain is well known, but this is not the case for other common and seemingly alarming defects like fissures.

The grading standards in Europe for structural timber grading are DIN 4074 (1) (Germany), BS 4978 (2) (United Kingdom), NF B 52001 (3) (France), INSTA 142 (4) (Nordic countries) and UNE 56544 (5) (Spain). Most of these standards have been developed for commercial sizes with thicknesses of 35 to $100 \mathrm{~mm}$ and a maximum width of $300 \mathrm{~mm}$.

The limitation of size of drying fissures in application of these standards is not an easy task. Although drying fissures cause alarm in inexpert users, grading rules are usually very tolerant of this defect. The percentage of rejected pieces because of fissures is usually low, but it strongly restricts the highest grades. This leads to the belief that the influence of fissures on mechanical properties is relatively low. This problem arises with large cross section pieces for the French standard (6) giving rise to the need to modify the standard for large cross-sections.

\subsection{Types of fissures}

Fissures are generally defined in the EN 844-9 (7) standard as any separation of fibers (splits or checks) in a longitudinal direction. Different kinds of fissure are normally classified depending on their origin or shape:

- Drying fissures: these are produced during timber drying. When the moisture content of timber is decreasing, the shrinkage tangentially direction is much greater than it is radially (approximately double), giving rise to internal stresses that produce the separation (rupture) of fibers (fissures).

- Lightning shakes: fissures caused by a lightning.

- Surface check: fiber separation in the face or the edge surface but without relevant penetration, so that surface planning is enough to eliminate it.

- Frost crack: radial fissure caused by freezing in standing trees. It affects the cross section from the exterior surface to the pith and is long.

- Felling shake: this is caused during felling of the tree and appears in the thicker part of the trunk, spreading longitudinally. 
- Fenda pasante: fenda que atraviesa totalmente la pieza.

- Fendas de viento: se producen cuando el árbol en pie se ve sometido a esfuerzos extraordinarios del viento que producen tensiones muy elevadas llegando a la rotura.

Otros fenómenos que pueden causar fendas de diferente naturaleza son los incendios durante el crecimiento del árbol, las tensiones elevadas durante el transporte y primera transformación, etc.

Las fendas de secado se presentan de manera habitual y generalizada en la madera, manifestándose en mayor o menor medida según la calidad del secado. En piezas de gran escuadría se manifiestan con mayor intensidad y su presencia es prácticamente inevitable. Por ello, para especificar calidades de la madera para uso estructural mediante las normas de clasificación visual sólo se tienen en cuenta las fendas de secado y otros tipos de fendas menos generalizados no suelen admitirse.

Conviene señalar que las fendas de secado no son en sí mismas un defecto de la madera, puesto que la fibra y el material conservan íntegramente sus propiedades. Desde un punto de vista mecánico, las fendas sólo suponen una separación de las fibras y un cambio de forma en la sección pero no una disminución de la sección resistente ni de las propiedades mecánicas del material.

\subsection{Formación de fendas de secado}

Los cambios de humedad que producen inestabilidad dimensional de la madera y que provocan la formación de las fendas son los que afectan al agua contenida en las paredes celulares, y que representan contenidos de humedad inferiores al 30\% (punto de saturación de la fibra).

Es posible estimar la magnitud esperada de las fendas si se conocen los contenidos de humedad inicial y en equilibrio higroscópico final de la madera, así como los coeficientes de contracción radial y tangencial. Un ejemplo se describe a partir de unos valores genéricos para una madera de conífera (Figura 1):

- Contenido de humedad inicial: $30 \%$

- Contenido de humedad final en equilibrio higroscópico: $12 \%$

- Dimensión inicial: $\mathrm{h}=200 \mathrm{~mm}$

- Coeficiente de contracción radial: 0,12\%/\%

- Coeficiente de contracción tangencial: 0,21\%/\%

- Dimensión radial final: $\mathrm{a}=200 \times(1-(30-12) \times 0,12$ / 100) = $196 \mathrm{~mm}$

- Dimensión tangencial final: $b=200 \times(1-(30-12)$ $x$ 0,21 / 100) $=192 \mathrm{~mm}$

- Estimación del espesor de la fenda: 196 - $192=4 \mathrm{~mm}$
- Split: fissure passing through the whole cross section of the piece.

- Wind shake: this is caused by extraordinary wind forces in standing tree that produce high stresses causing rupture.

One kind of fissure known as ring shakes consists of a discontinuity between growing rings. Other causes of fissures exist, such as fire during growing of the tree, high stresses during transport and initial processing, etc.

Drying fissures are common in general in timber, and their size depends on the quality of drying. They are bigger in large cross section pieces and are practically unavoidable. This is the reason why visual grading standards usually only accept and limit drying fissures, while other kinds of fissures are not accepted.

It is important to note than drying fissures are not in themselves a defect in the material, because the fibers and material keep their properties intact. From a mechanical point of view fissures only imply a longitudinal separation of fibers and some changes in the cross section but without any reduction of the mechanical properties of the material.

\subsection{The origin of drying fissures}

The changes in moisture content that cause changes to the volume of timber and drying fissures are those that affect the water content in the wall cells, and correspond to moisture contents lower than $30 \%$ (fiber saturation point).

It is possible to estimate the size of fissures if the initial moisture content and the final equilibrium moisture content of timber are known, together with the radial and tangential shrinkage coefficients. An example is described using average values of coniferous timber (Figure 1):

- Initial moisture content: $30 \%$;

- Final equilibrium moisture content: $12 \%$;

- Initial dimension: $b=200 \mathrm{~mm}$;

- Radial shrinkage coefficient: $0.12 \% / \%$;

- Tangential shrinkage coefficient: $0.21 \% / \%$;

- Final radial dimension: $a=200 \times(1-(30-12) \times 0.12$ / 100) = $196 \mathrm{~mm}$;

- Final tangential dimension: $b=200 \times(1-(30-12)$ $x$ 0.21 / 100) = $192 \mathrm{~mm}$;

- Estimation of fissure thickness: $196-192=4 \mathrm{~mm}$. 
Esta estimación no es del todo precisa, ya que la dimensión " $b$ " no se encuentra en dirección completamente tangencial.
This estimation is only approximate because dimension " $b$ " is not in exactly tangential.

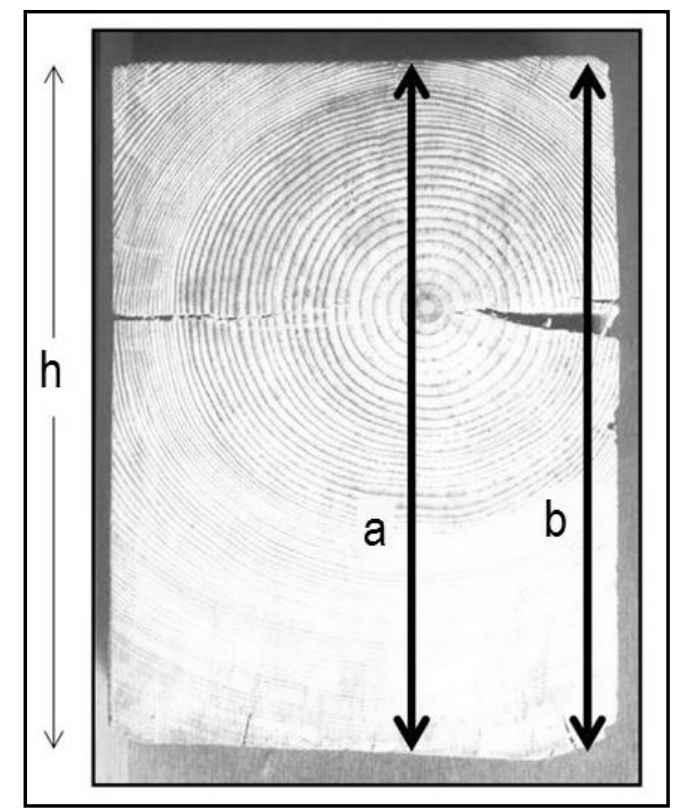

Figura 1. Estimación de la magnitud de las fendas de secado. Figure 1. Estimation of the magnitude of drying fissures.

\subsection{Criterios para la medición de fendas en la clasificación visual}

El criterio de clasificación de las fendas en la norma española UNE 56544 se basa en la medición de su profundidad ( $f$ ) en relación al ancho de la pieza (b) (Figura 2, Tabla 1) (5). Sólo se tienen en cuenta las fendas que son mayores de $1 \mathrm{~m}$ de longitud o un cuarto de la longitud de la pieza, así como las que tienen un espesor superior a $1 \mathrm{~mm}$.

\subsection{Measuring fissures for visual grading}

The criterion for measuring fissures in Spanish visual grading Standard UNE 56544 (5) is based on depth evaluation ( $f$ ) divided by the width of the piece (b) (Figure 2, Table 1). Only fissures with a length of more than $1 \mathrm{~m}$ or a quarter of the length of the piece, and with a thickness of more than $1 \mathrm{~mm}$, are taken into account.

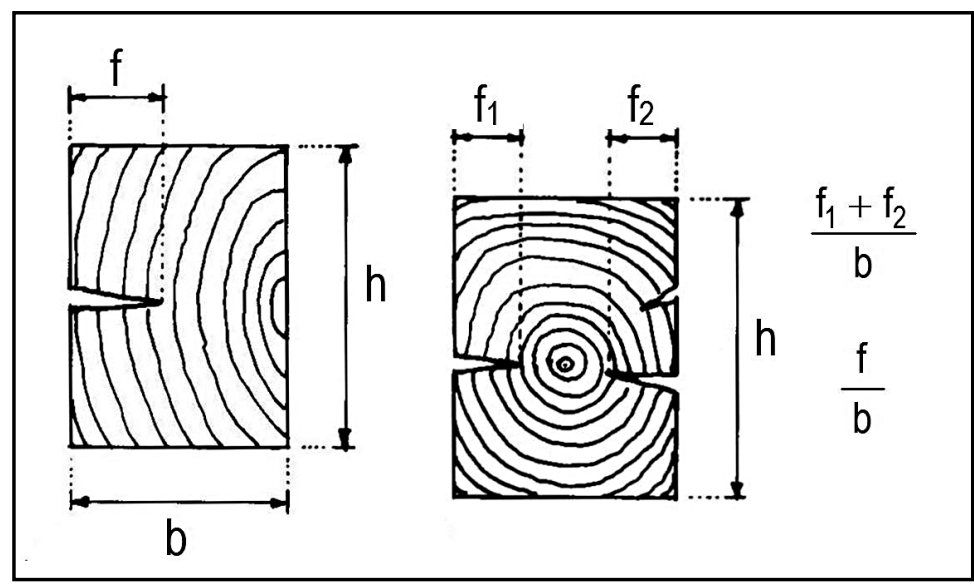

Figura 2. Medición de fendas según la norma UNE 56544:2007.

Figure 2. Measurements of fissures according to UNE 56544:2007. 
Tabla 1 / Table 1

Criterios de calidad para fendas según UNE 56544.

Specifications for fissures according to UNE 56544.

\begin{tabular}{|c|c|c|}
\hline & ME 1 & ME 2, MEG \\
\hline Fendas de secado / Drying fissures & $\mathrm{f} \leq \mathrm{b} \cdot 2 / 5$ & $\mathrm{f} \leq \mathrm{b} \cdot 3 / 5$ \\
\hline $\begin{array}{c}\text { Fendas de acebolladura, rayo, heladura o abatimiento / Ring shakes, lightning shake } \\
\text { or felling shake }\end{array}$ & No permitidas / Not accepted \\
\hline
\end{tabular}

Otras normas contemplan las fendas en piezas de gran escuadría de diferente modo. La norma INSTA 142 (4) de los países nórdicos define la gran escuadría como aquellas secciones en las que se cumple $b \geq 45 \mathrm{~mm}$ ó $\mathrm{h} \geq 70 \mathrm{~mm}$, y establece cuatro calidades (T3, T2, T1 y T0) para las que se limita la longitud de las fendas (Tabla 2).
Other grading standards consider fissures in large cross section pieces in a different way. The Nordic countries visual grading standard INSTA 142 (4) defines large cross sections as pieces with dimensions of cross section, thickness $b \geq 45 \mathrm{~mm}$ or width $h \geq 70 \mathrm{~mm}$, and it establishes four grades (T3, T2, T1 y TO) with different limit for fissures, Table 2.

Tabla 2 / Table 2

Criterio de fendas según INSTA 142.

Specifications for fissures according to INSTA 142.

\begin{tabular}{|c|c|c|c|}
\hline & T3 & T2 & T0 \\
\hline $\begin{array}{l}\text { Fendas superficiales I } \\
\text { Surface checks }\end{array}$ & No aceptadas / Not accepted & $\begin{array}{l}\text { No aceptadas si su longitud es }>1 / 4 \text { de la cara exterior / } \\
\text { Not accepted if its length is }>1 / 4 \text { external face }\end{array}$ & Aceptadas / Accepted \\
\hline \multirow{4}{*}{$\begin{array}{l}\text { Fendas de secado / } \\
\text { Drying fissures }\end{array}$} & $\begin{array}{c}\text { Longitud } \leq \mathrm{L} / 2 / \\
\text { Length } \leq \mathrm{L} / 2\end{array}$ & Longitud $\leq \mathrm{L}$ / Length $\leq \mathrm{L}$ & \multirow{4}{*}{ No pasantes / Not through } \\
\hline & $\begin{array}{l}\text { No contínuas / } \\
\text { Not continuous }\end{array}$ & $\begin{array}{l}\text { No continuas / } \\
\text { Not continuous }\end{array}$ & \\
\hline & $\begin{array}{l}\text { No pasantes / } \\
\text { Not through }\end{array}$ & No pasantes / not through & \\
\hline & $\begin{array}{l}\text { No en los cantos / } \\
\text { Not on edges }\end{array}$ & $\begin{array}{l}\text { No en los cantos / } \\
\text { Not on edges }\end{array}$ & \\
\hline
\end{tabular}

La norma DIN 4074 (1) de aplicación en centro y norte de Europa define 3 calidades (S13, S10 y S7) y distingue las piezas por su tamaño en:

- listones: $\mathrm{b}<40 \mathrm{~mm}, \mathrm{~h}<80 \mathrm{~mm}$

- tablas: $\mathrm{b} \leq 40 \mathrm{~mm}, \mathrm{~h} \geq 80 \mathrm{~mm}$

- tablones: b $>40 \mathrm{~mm}, \mathrm{~h}>3 \cdot \mathrm{b}$

- madera escuadrada: $\mathrm{b}>40 \mathrm{~mm}, \mathrm{~b} \leq \mathrm{h} \leq 3 \cdot \mathrm{b}$

Los tamaños de tablón (trabajando de canto y sometido a flexión) y madera escuadrada son considerados de gran escuadría. Esta norma mide la profundidad de las fendas igual que la UNE 56544 (5) (Tabla 3).
The German visual grading Standard DIN 4074 (1) for Central and Northern Europe establishes 3 grades (S13, S10 y S7) and considers different kinds of pieces depending on their size:

- battens: $b<40 \mathrm{~mm}, h<80 \mathrm{~mm}$

- boards: $b \leq 40 \mathrm{~mm}, h \geq 80 \mathrm{~mm}$

- planks: $b>40 \mathrm{~mm}, h>3 \cdot b$

- squared timber: $b>40 \mathrm{~mm}, b \leq h \leq 3 \cdot b$

Planks in edge bending and squared timber are evaluated as large cross section pieces for the purpose of visual grading. The procedure for the evaluation of the depth of fissures in this standard is the same as in UNE 56544 (5), Table 3.

Tabla 3 / Table 3

Criterio de fendas según DIN 4074.

Specifications for fissures according to DIN 4074

\begin{tabular}{|c|c|c|}
\hline & $\mathrm{s} 13$ & $\mathrm{~s} 10$ \\
\hline Fendas de secado / Drying fissures & $\mathrm{f} \leq \mathrm{b} \cdot 2 / 5$ & $\mathrm{f} \leq \mathrm{b} \cdot 1 / 2$ \\
\hline $\begin{array}{l}\text { Fendas de rayo, heladura o acebolladura / } \\
\text { Lightning shake, frost crack or ring shakes }\end{array}$ & No admitidas / Not accepted \\
\hline
\end{tabular}




\subsection{Objetivos}

Este trabajo pretende un acercamiento al conocimiento de la influencia de las fendas en la capacidad resistente de la madera para uso estructural. Para ello, el objetivo principal del trabajo se plantea desde tres puntos de vista:

- Diseñar una metodología válida para el estudio de las fendas que permita medirlas y cuantificarlas.

- Realizar ensayos que permitan estimar la influencia de las fendas de secado en las propiedades mecánicas.

- Establecer el mejor estimador para la evaluación y cuantificación de las fendas de secado a partir de parámetros de fácil medición.

\subsection{Antecedentes}

La resistencia de vigas de madera con fendas ha sido objeto de estudio desde hace tiempo. En 1934 el Departamento de Mecánica de la Madera del Forest Products Laboratory de Madison llevó a cabo una investigación enfocada a revisar los procedimientos habituales de comprobación de vigas a cortante (8-9). La capacidad de carga de vigas con fendas obtenida experimentalmente mediante el fallo por cortante resultaba ser muy superior a los valores estimados por los métodos de cálculo habituales.

A través de un análisis teórico de las vigas con fendas y un conjunto de ensayos sobre cerca de 200 vigas fabricadas por encolado de 5 piezas de madera, formando secciones con fendas artificiales en la mitad de sus caras, se logró una primera aproximación al comportamiento real de este problema. Llegaron a la conclusión de que la carga última por cortante en una viga con carga uniforme y con fendas puede estimarse a partir de la tensión tangencial obtenida con el cortante descontando la carga situada a una distancia inferior a la altura de la viga (h) desde el apoyo y estimando la proporción entre el área sin fendas y el área total en el plano neutro comprendido entre el apoyo y una sección situada a tres veces la altura de la viga. Además, se aplica una reducción de 4/9 en la resistencia, debida a la concentración de tensiones producida por las fendas.

La capacidad de carga de una viga a cortante podría basarse en la carga máxima que puede resistir. Con este criterio, la existencia de fendas en la pieza no resultaría relevante ya que aunque el fendado llegue a dividir la pieza en dos mitades independientes, cada una resistiría aproximadamente la mitad del cortante total. Sin embargo, una pieza dividida en dos mitades difícilmente cumpliría los requisitos de rigidez y resistencia a flexión, ya que su rigidez global sería cuatro veces menor y su capacidad

\subsection{Objectives}

The aim of this work is to study the influence of fissures on the bearing capacity of structural timber. To this end the three following subjects are covered:

- The design of a methodology for the evaluation of fissures, measuring and evaluating them in detail.

- Mechanical testing to evaluate if there is a relevant influence on the load bearing capacity of timber.

- To establish the best estimator for the evaluation of drying fissures using parameters that are easy to measure.

\subsection{Background}

Mechanical properties of timber specimens with fissures have been evaluated for many years. In 1934, the Timber Mechanics Section of the Forest Products Laboratory in Madison carried out a research review to analyze the shear strength evaluation methods used until then for the load-carrying assessment of timber pieces (8-9). Shear load-bearing capacity of fissured beams obtained by means of testing (those pieces showed shear failure mode) was much higher that the values estimated by usual shear strength calculation methods.

The first satisfactory approach to the real problem was achieved through the theoretical analysis of fissured beams and the subsequent testing of 200 specimens, each made of 5 glued timber pieces, while keeping artificial side fissures in the middle plane of the section depth. It was concluded that the ultimate load at which failure in a fissured and uniformly loaded timber beam may be expected can be estimated with fair accuracy from the shear force; this is without considering the loads situated within a distance from the support less than the depth of the beam section. The ratio of fissured area to total area at the neutral plane between the support and a point located at three times the depth of the beam from the support is estimated. Furthermore, a reduction of 4/9 of the strength is applied; this factor represents the reduction in load capacity due to concentration of stress at the end of the checks.

The shear load-carrying capacity of a timber beam could be estimated by means of the ultimate load at which failure occurs. Based on this criterion, the existing fissures in a beam would not be relevant because even though fissures would divide the whole piece into two independent halves, each half would resist half part of the total shear force. Nevertheless, a piece divided in two parts is unlikely to meet the bending strength and stiffness requirements. This is because stiffness would 
de carga a flexión dos veces menor. Por tanto, en la práctica es necesaria una limitación del tamaño de las fendas.

El efecto de la longitud de las fendas pasantes de testa ha sido analizado con el fin de llegar a establecer unas tensiones admisibles a cortante (10). Mediante un análisis de mecánica de fractura elástico y lineal se llegó a establecer una expresión aproximada de un coeficiente de corrección de los valores de la resistencia a cortante. Las conclusiones de este estudio eran que para el tamaño de las fendas de testa admitidas generalmente, en las calidades de madera aserrada, las reducciones de resistencia definidas por la norma ASTM D245 (11) eran demasiado conservadoras.

Para determinar la resistencia a cortante de una viga mediante un ensayo de flexión es precisa una disposición de poca esbeltez (relación luz/canto de la viga menor o igual a 5). No obstante, aun así, es difícil conseguir un alto porcentaje de fallos por cortante. En investigaciones realizadas para relacionar la resistencia a cortante con los métodos no destructivos (12) se realizaron ensayos de flexión con carga concentrada sobre un total de 194 piezas de varias especies de coníferas con sección transversal de $100 \times 100 \mathrm{~mm}$. La luz de ensayo era igual a 5 veces el canto h de la viga y se obtuvo un $7 \%$ de fallos por cortante frente a un $67 \%$ por flexión y un $26 \%$ de difícil interpretación.

Con las proporciones habituales entre luz y tamaño de la sección en la práctica es muy baja la probabilidad de alcanzar un fallo por cortante; lo normal es que la rotura se produzca antes por flexión. Cuanto mayor sea la resistencia a flexión de la viga mayor probabilidad existe de agotar su resistencia por cortante. Esto puede comprobarse en el trabajo de investigación sobre las propiedades mecánicas de tres especies de madera de procedencia española (Pinus radiata D. Don, Pinus sylvestris L. y Pinus laricio Arnold) en el que se ensayaron un total de 395 piezas según la norma EN 408 con una esbeltez, luz/canto, igual a 18 (13). Se diferenciaron tres modos de rotura: por flexión, por cortante y mixto (flexión y cortante de difícil distinción). El porcentaje de fallos por cortante era nulo en el pino radiata (el de menor resistencia a flexión), 4,2\% en el pino silvestre y $7,5 \%$ en el pino laricio (el de mayor resistencia a flexión). Se constata que el porcentaje de fallo por cortante es mayor cuanto mayor es la resistencia a flexión.

Es interesante un trabajo realizado para reducir las fendas de secado en piezas de gran escuadría consistente en la realización de un agujero de $58 \mathrm{~mm}$ de diámetro a lo largo de piezas de abeto (Red spruce) de $5 \mathrm{~m}$ de longitud y sección de 170×220 mm aproximadamente (14). El agujero disminuye la formación de fendas y además be four times less while bending load-bearing capacity would be two times lower. Due to this and practical issues fissure size should be limited.

The effect of the length of end splits has been studied to determine allowable shear stresses (10). Concepts of linear elastic fracture mechanics were used to define a correction coefficient for shear strength values. This work concluded that for the end splits currently associated with the different grades of dimension lumber, the strength ratios given by ASTM D245 (11) are too conservative and that allowable stresses could be increased.

To determine the shear strength of a beam by means of bending testing, a low slenderness test configuration (span/depth of the beam ratio up to 5) should be considered. Nevertheless, it is quite difficult to obtain a high percentage of shear mode failures as a result. Some research studies evaluated the shear strength of timber by non-destructive methods (12) and performed 194 concentrated load bending tests on several coniferous species and $100 \times 100 \mathrm{~mm}$ cross section specimens. The test span was 5 times the depth of the beam and the results were only $7 \%$ of failures in shear mode, $67 \%$ of failures in bending mode and $26 \%$ in a failure mode difficult to evaluate.

Thus by using standard span/section size ratios it is rare to obtain shear failure modes; on the other hand, failure will occur first by bending. The higher is the bending strength of a piece, the higher is the probability is of surpassing its shear strength. This is easy to confirm by checking the results of a mechanical properties assessment project covering three Spanish coniferous species (Pinus radiata D. Don, Pinus sylvestris $L$. and Pinus laricio Arnold). In this, 395 structural size pieces were tested according to the European EN 408 standard, using a slenderness, span/depth of the section, equal to 18 (13). Three different failure modes were considered: bending mode, shear mode and mixed (meaning that bending and shear were hard to interpret). Shear failure mode percentages were: zero in radiata pine (lower bending strength group), $4.2 \%$ in Scots pine and $7.5 \%$ in laricio pine (higher bending strength group). It is confirmed that higher percentages of shear failure modes are achieved when bending strength is higher too.

It is also interesting to remark another research study on reducing drying fissures in large-cross section timber, based on the execution of a $58 \mathrm{~mm}$ diameter hole through the whole length of Red spruce beams, $5 \mathrm{~m}$ long and $170 \times 220 \mathrm{~mm}$ cross-section (14). The hole reduces the drying fissuring process and aids balanced drying. No 
facilita un secado más equilibrado. No se observaron diferencias significativas para la resistencia entre las vigas taladradas y las no taladradas.

Esta metodología de ensayo puede ser mejorada como fue el caso de los ensayos realizados sobre 30 vigas de madera laminada encolada de abeto (Picea abies L.) con el fin de obtener el valor característico de la resistencia a cortante (15). El trabajo presenta dos aportaciones de gran interés. En primer lugar, se obtuvo un $60 \%$ de piezas que fallaron por cortante (objetivo principal) y un $40 \%$ por flexión. Las vigas tenían una sección de $140 \times 456 \mathrm{~mm}$ y una luz de $3.048 \mathrm{~mm}$. Se aplicaban dos cargas concentradas centradas en el vano y con una separación entre ellas de $508 \mathrm{~mm}$. Es decir, la luz de la viga era de 6,68 veces el canto y la distancia entre cargas de 1,11 veces el canto.

Además, de las 12 láminas de $38 \mathrm{~mm}$ de espesor que formaban la sección, las tres extremas de cada lado eran de una clase resistente muy superior a la clase resistente de las láminas centrales, con el fin de alejarse en lo posible del fallo por flexión.

Generalmente, existen dos opciones para abordar el análisis de los resultados así obtenidos. En el caso anterior, un $60 \%$ de los resultados son válidos al obtener la resistencia a cortante, pero el restante $40 \%$ son resultados de la tensión de cortante existente en el momento de la rotura. Una posibilidad es considerar todos los resultados (resistencias a cortante y tensiones de cortante en el momento de la rotura) como válidos. La otra posibilidad es considerar únicamente como válidos los resultados de las resistencias a cortante, perdiendo la información de los restantes datos. Ambas opciones son incompletas, por lo que este estudio abordó el problema aplicando la teoría estadística de los datos incompletos.

La técnica no destructiva de ultrasonidos ha sido utilizada para detectar grietas longitudinales en piezas de madera laminada encolada (16). La experiencia consistió en tomar lecturas con un equipo de ultrasonidos en una pieza de madera laminada encolada de dimensiones de 120x440 mm de sección transversal con una longitud de $2.100 \mathrm{~mm}$, en la que existía una grieta longitudinal que se extendía hasta aproximadamente la mitad de la longitud. Se realizaron lecturas desde la cara superior a la cara inferior registrando tres parámetros: tiempo de transmisión, amplitud del pico y primera amplitud. La comparación entre la inspección visual y los parámetros de ultrasonidos alcanzaba un grado de ajuste suficiente para determinar la longitud de la grieta.

El estudio de la influencia de los defectos en la madera estructural en piezas de gran escuadría ha sido objeto de statistically significant differences between holed and unholed beams were found.

This test method could be improved, as is shown by tests performed on thirty combined glulam beams to determine their characteristic shear strength (15). This work presents two main findings that are full of interest. Firstly, $60 \%$ of pieces failed in shear mode (the targeted objective) and $40 \%$ in bending mode. Specimens had a cross section size of $140 \times 456 \mathrm{~mm}$ and a span of 3048 $\mathrm{mm}$. Two concentrated loads were applied centred and with $508 \mathrm{~mm}$ between them. This means that the length of the beam was 6.68 times its depth, and the distance between loads was 1.11 times the depth of the beam.

The beams consisted of twelve laminations manufactured with Spruce (Picea abies L.), each having a thickness of 38 $\mathrm{mm}$. In order to prevent bending failure, the lay-up of the laminations was combined: the three outermost laminations in the tension and compression side, respectively, had higher strength class assignment.

In general, there are two approaches to performing the statistical analysis of such data sets. $60 \%$ of results represent shear strength, and the other $40 \%$ are shear stresses at failure time. A common approach in such a situation is simply not to distinguish between shear strengths and shear stresses at the rupture load and to evaluate all of the data combined. An alternative to that approach may be to exclude shear stresses and only analyze the subset of shear strength values. Both engineering approaches are inappropriate. Due to this the paper in question used censored observations statistical theory.

Non-destructive techniques such as ultrasound have also used to detect longitudinal fissures in glulam pieces (16). The research consisted of ultrasound wave readings in $2100 \mathrm{~mm}$ long and $120 \times 440 \mathrm{~mm}$ crosssection over a glulam beam with a longitudinal fissure from its end to half-way along it. Measurements were performed from the top to the bottom face of the beam (perpendicular to the grain) and three values were recorded: time of flight, peak-to-peak amplitude and first amplitude of the signal. Comparison between visual inspection and ultrasound parameters make it possible to determine fissure length.

In-depth studies of the influence of timber singularities on large cross-section structural timber have been 
varios trabajos de investigación en España orientados hacia la evaluación de la capacidad resistente de la madera en estructuras existentes (17-18). En algunos de ellos se ha analizado el efecto de defectos poco estudiados como son las fendas y las gemas (19-20).

\section{MATERIALES Y MÉTODOS}

La metodología general se basa en el estudio de 28 piezas de madera en las que se miden con un alto nivel de detalle los parámetros relacionados con las fendas de secado y se someten a un ensayo mecánico para determinar su resistencia. El estudio de resultados se basa en el análisis de relaciones entre variables.

\subsection{Material de ensayo}

Las 28 piezas estudiadas son de madera de pino silvestre (Pinus sylvestris L.) de gran escuadría procedentes de estructuras existentes, con longitudes desde 660 a $1.080 \mathrm{~mm}$ y secciones variadas desde $108 \times 140 \mathrm{~mm}$ a $111 \times 211 \mathrm{~mm}$. Proceden de un edificio de finales del siglo XVIII situado en Aranjuez, provincia de Madrid.

Estas piezas reúnen las condiciones adecuadas para llevar a cabo el estudio:

- presentan fendas generalizadas y de diferente magnitud;

- sus dimensiones permiten llevar a cabo un estudio detallado de las fendas;

- su longitud y sección permiten realizar ensayos mecánicos de flexión con carga central para aumentar el efecto del esfuerzo cortante.

\subsection{Corte de las piezas}

Se procedió a regularizar las dimensiones de las piezas rebajando su sección original a un rectángulo inscrito, obteniendo dos lotes de dimensiones 100x120 y 100x150 $\mathrm{mm}$ con el objeto de homogenizar el estudio y los resultados (Figura 3). carried out in Spain. Several centred on the load-bearing capacity of existing structures (17-18). Singularities that are not often studied such as fissures and waves were analyzed in some of these studies (19-20).

\section{MATERIALS AND METHODOLOGY}

The general methodology is based on the study of 28 wood pieces in which the parameters related to drying fissures were measured with a high level of detail and were also tested to determine strength. The study of results is based on analysis of relationships between variables.

\subsection{Testing material}

The 28 samples studied are large cross-section Scots pine (Pinus sylvestris L.) pieces from existing structures, with lengths from 660 to $1080 \mathrm{~mm}$ and sections from $108 \times 140 \mathrm{~mm}$ to $111 \times 211 \mathrm{~mm}$. They come from a building of the end of the XVIII century located in Aranjuez, in the province of Madrid.

These pieces have suitable conditions for this study:

- they shown generalized fissures of different sizes;

- their dimensions make it possible to carry out a detailed study of fissures;

- their length and section permit mechanical bending tests with concentrated midpoint load to increase the weight of shear.

\subsection{Cutting the pieces}

The original dimensions of the pieces have been reduced to an inscribed rectangle in order to regularize the dimensions into two groups, at $100 \times 120$ and $100 \times 150 \mathrm{~mm}$ respectively (Figure 3).

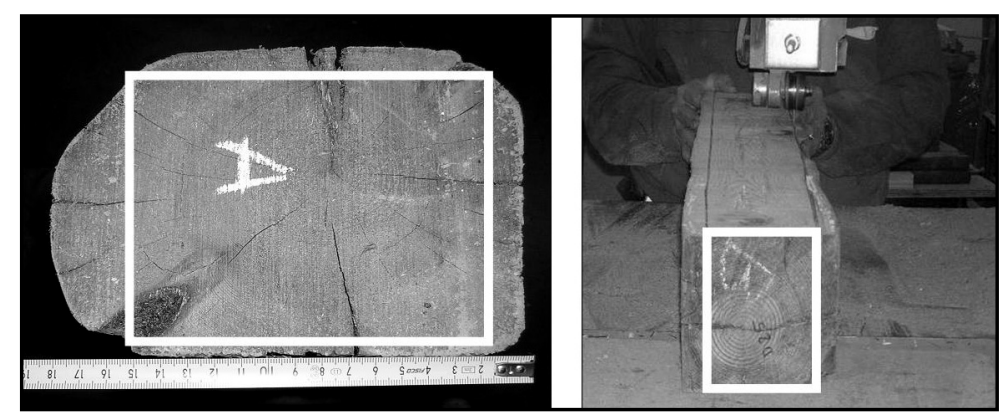

Figura 3. Sección rectangular y corte de las piezas.

Figure 3. Rectangular cross section and resizing of the pieces. 


\subsection{Medición de fendas}

Los parámetros de fendas evaluados son los siguientes:

- Espesor.

- Inclinación.

- Longitud.

- Profundidad.

- Superficie eficaz.

\section{Espesor}

Se han definido dos tamaños de fendas según el espesor (Figura 4):

- Grupo I: fendas con poca importancia, o poco aparentes con espesor $\leq 5 \mathrm{~mm}$.

- Grupo II: fendas importantes, o muy aparentes, con espesores $>5 \mathrm{~mm}$.

En cada pieza se mide por las dos caras el espesor máximo de cada fenda y se hace el promedio de todos ellos (Figura 5).

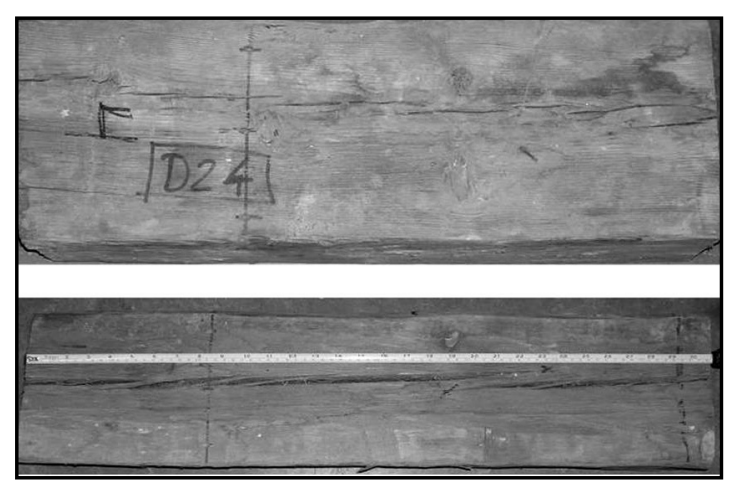

Figura 4. Fendas del grupo I (4a) y del grupo II (4b). Figure 4. Fissures of group I (4a) and group II (4b).

Por otro lado, también se registra el valor máximo de espesor de fendas en cada pieza. Es decir, el espesor de la fenda más gruesa de cada pieza.

\section{Inclinación de fendas}

La inclinación de las fendas se corresponde con la desviación de la fibra. De acuerdo con la norma UNE EN 844-9 (7), se denomina desviación de la fibra a su desviación con respecto del eje longitudinal de la pieza. Se midió la inclinación media de todas las fendas y la inclinación máxima.

Para obtener la inclinación media de cada pieza se han medido los ángulos de inclinación de las fendas con

\subsection{Measurement of fissures}

The following parameters of fissures were evaluated:

- Thickness.

- Inclination.

- Length.

- Depth.

- Effective Surface.

\section{Thickness}

Two sizes of fissures were defined according to the thickness (Figure 4):

- Group I: minor fissures with thickness $\leq 5 \mathrm{~mm}$.

- Group II: fissures with thickness > $5 \mathrm{~mm}$.

In each piece, the maximum thickness of each fissure was measured on both faces, and the average value of all of them was recorded (Figure 5).

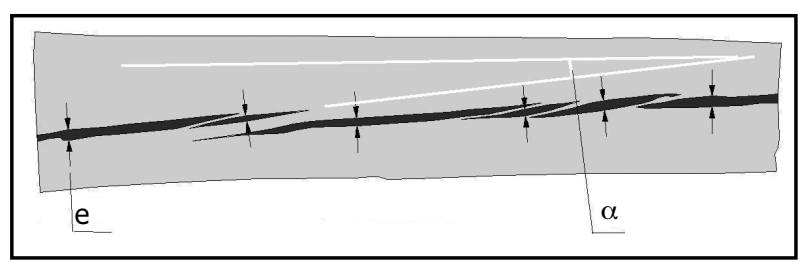

Figura 5. Medición del espesor (e) y desviación de la fibra $(\alpha)$. Figure 5. Measurement of the thickness (e) and the slope of grain $(\alpha)$.

On the other hand, the maximum value of the thickness of fissures in each piece was recorded, i.e., the thickness of the thickest fissure in each piece.

\section{Inclination of fissures}

The inclination of fissures corresponds to the deviation of the fiber. According to the UNE-EN 844-9 (7) standard, slope of grain is the deviation with respect to the longitudinal axis of the piece. The mean value of the inclination of all the fissures and the maximum value were recorded.

In order to obtain the average value of the inclination of each piece, several measurements of the deviation of 
respecto al eje longitudinal, realizando varias mediciones por cada cara y calculando el valor medio. El valor máximo de inclinación se toma de entre las mediciones realizadas, descartando posibles desviaciones locales más acusadas (Figura 5).

\section{Longitud de fendas}

Se evaluó la longitud de las fendas mediante índices globales y parciales:

- índice global o longitud relativa,

- longitud máxima.

El índice global o longitud relativa se obtiene midiendo y sumando la longitud de todas las fendas, y se expresa en porcentaje sobre la longitud total de la pieza [ecuación 1]: each fissure with respect to the longitudinal axis were made, and the average value of the measurements was obtained. The maximum value is obtained from the measurements carried out, discarding local deviations (Figure 5).

\section{Length of fissures}

The length of fissures was evaluated using global and partial index:

- global index or relative length,

- maximum length.

The global index or relative length is obtained by measuring and adding the length of all the fissures, expressed as a percentage of the length of the piece [equation 1]:

$$
\mathrm{i}_{\mathrm{L}}=\frac{\sum \mathrm{I}}{\mathrm{L}_{\mathrm{t}}} \mathrm{x} 100
$$

Siendo $\Sigma l$ el sumatorio de las longitudes de las fendas por ambas caras y $L_{t}$ la longitud de la pieza multiplicada por dos. Este índice puede ser superior al $100 \%$ debido al solape longitudinal de unas fendas con otras.

La longitud máxima es la longitud de la fenda más larga.

\section{Profundidad de fendas}

Para evaluar la profundidad de las fendas se registran en cada pieza los siguientes parámetros:

- Profundidad máxima.

- Profundidad media.

En cada pieza se mide la profundidad de las fendas por ambas caras utilizando una galga de 0,2 $\mathrm{mm}$ de grosor. Según la norma UNE 56544 (5) no se tienen en cuenta las fendas que tengan longitud inferior a $1 \mathrm{~m}$ o un cuarto de la longitud de la pieza, ni las fendas cuya anchura no supere $1 \mathrm{~mm}$. El valor de profundidad se expresa en relación a la anchura de la pieza.

Se toman medidas de profundidad en varios puntos a lo largo de la fenda: en los extremos (a tres centímetros del extremo de la fenda) y en puntos intermedios no dejando una separación entre ellos superior a $10 \mathrm{~cm}$. Estas mediciones permiten una representación gráfica en planta de las fendas a lo largo de la pieza (Figura 6).

\section{Superficie eficaz}

La presencia de las fendas supone una reducción de la sección en el plano medio de las piezas, lo que implica
Where $\Sigma l$ is the sum of the lengths of all the fissures on both faces of each piece and $L_{t}$ the length of the piece multiplied by two. This index can be greater than 100\%, due to longitudinal overlaps of some fissures with others.

The maximum length is the length of the longest fissure.

\section{Depth of fissures}

In order to evaluate the depth of fissures the following parameters were recorded for each piece:

- Maximum depth.

- Medium depth.

In each piece the depth of the fissures in both faces was measured using a $0.2 \mathrm{~mm}$ thick gauge. According to the UNE 56544 (5) standard, fissures with a length less than a quarter of the length of the piece or $1 \mathrm{~m}$ are not considered, and nor are the fissures less than $1 \mathrm{~mm}$ thick. The depth value is expressed in relation to the width of the piece.

Depth measurements were taken at several points along the fissure: at the ends (three centimeters from the end of the fissure) and at intermediate points spaced not more than $10 \mathrm{~cm}$. These measurements make it possible to generate a horizontal graphic representation of the fissures along the piece (Figure 6).

\section{Effective surface}

The presence of fissures means that there is a reduction of the area in the horizontal middle plane of the pieces. 
una reducción del plano de rasante en la zona de tensiones tangenciales máximas. Ello dará lugar a un aumento de las tensiones debidas al cortante.

Esta pérdida de sección resistente se expresa a partir de la misma representación gráfica mediante la medición de la superficie de madera no afectada por las fendas (superficie eficaz) respecto a la superficie completa original.

En la representación gráfica en planta se observa que algunas fendas se solapan, por ello se han considerado dos superficies eficaces (Figura 6):

- teniendo en cuenta la superficie del solape a efectos de superficie resistente;

- no teniendo en cuenta la superficie solapada.
This implies a reduction of the area in the neutral axis plane, just in the fiber with maximum shear stress, resulting in an increase of shear stress.

This reduction of the resistant area is expressed in the graphic representation by measurement of the wood surface not affected by fissures (the effective surface) with respect to the original complete surface.

In the horizontal graphic representation some fissures are shown to overlap, so two effective surfaces have been considered (Figure 6):

- considering the surface of overlaps as resistant surface, A2;

- $\quad$ not considering the surface of overlaps as resistant surface, A3.

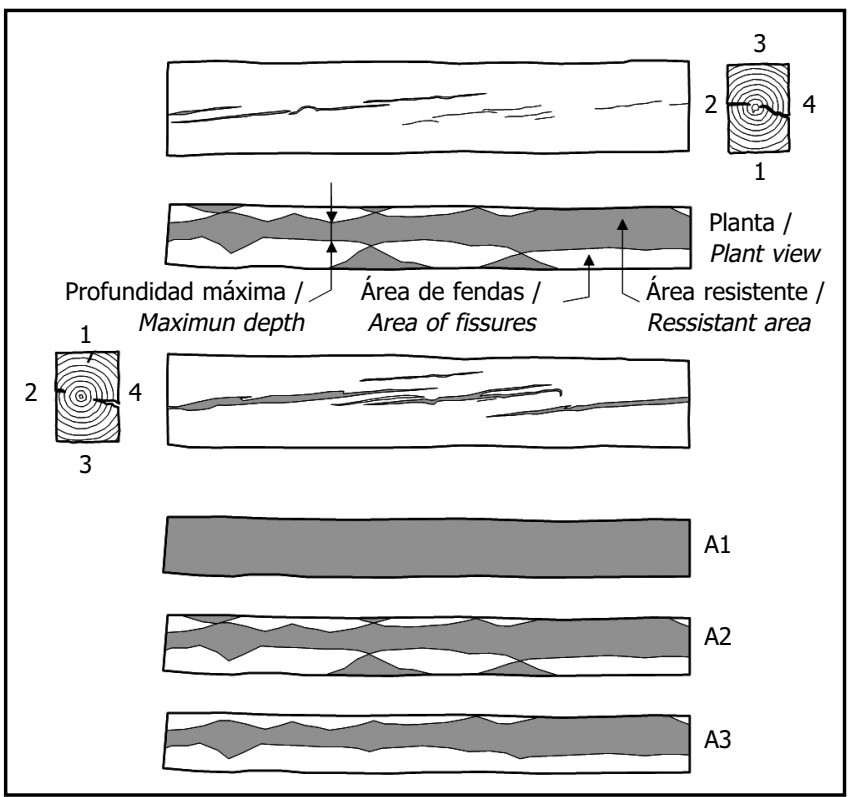

Figura 6. Esquema de las fendas en planta y área resistente. $A 1=$ Área total. $A 2$ = Área resistente incluyendo el solape de fendas. $\mathrm{A} 3$ = Área resistente sin contar con el solape.

Figure 6. Plant view of fissures and effective area. $A 1=$ Total area. $A 2=$ Effective area including overlaping of fissures. $A 3=$ Effective area without overlaping.

Se define el índice de áreas como la relación existente entre la superficie eficaz o superficie resistente de la pieza y la superficie total [ecuaciones 2]:
The index of area is defined as the existing relationship between the effective surface or resistant surface (A3, A2) and the total surface of the piece (A1) [equation 2]:

$$
i_{2}=\frac{A_{2}}{A_{1}} ; \quad i_{3}=\frac{A_{3}}{A_{1}}
$$

El significado físico de este índice es la proporción de madera resistente respecto a la superficie teórica de la pieza si no tuvieran fendas. El índice será tanto mayor cuanto menores sean las fendas y, como mucho, será igual a la unidad.
The physical meaning of this index is the proportion of resistant surface of wood with respect to the theoretical surface of the piece without fissures. The index of a piece with small fissures will be greater and the maximum value may be equal to the unit in a piece without any fissure. 


\subsection{Ensayo de flexión}

El módulo de elasticidad aparente y la resistencia a flexión se obtuvieron a partir del método de la luz única, siguiendo la norma UNE-EN 408 (21) (Figura 7).

\subsection{Bending test}

The bending strength and the apparent modulus of elasticity were obtained following the method of the UNE-EN 408 (21) standard (Figure 7).

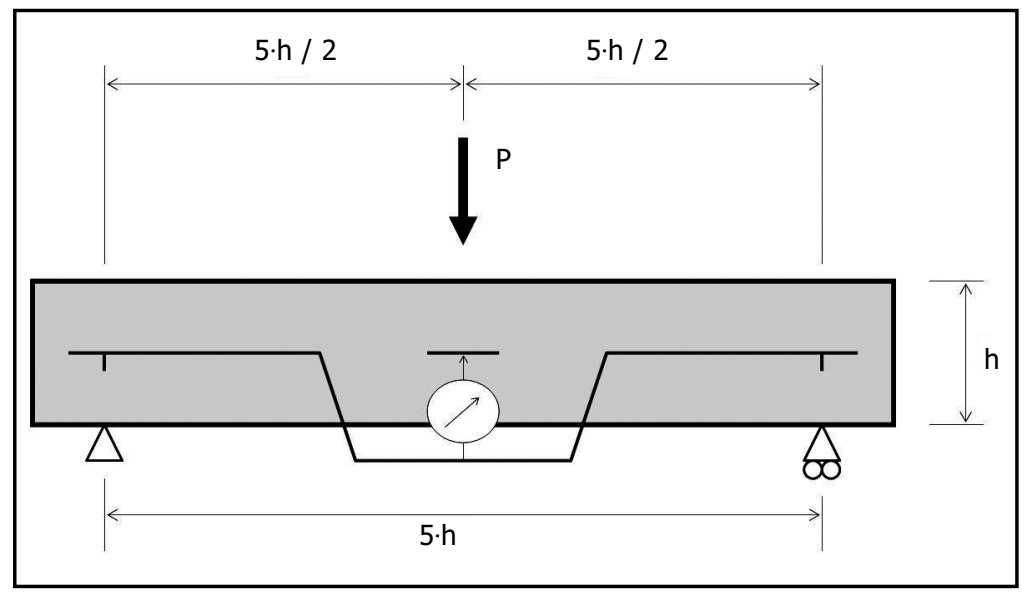

Figura 7. Ensayo a flexión.

Figure 7. Bending test.

La luz de ensayo es la correspondiente a cada grupo de piezas: las de $100 \times 150 \mathrm{~mm}$ se ensayan con una luz de $750 \mathrm{~mm}$ y las de $100 \times 120 \mathrm{~mm}$ con una luz de $600 \mathrm{~mm}$. Mediante el ensayo de flexión se determina la carga de rotura y el módulo de elasticidad aparente aplicando la carga con velocidad constante.

Con el resultado de los ensayos, para cada pieza se obtienen los siguientes datos:

- tensión máxima de flexión en el momento de la rotura;

- tensión máxima de cortante en el momento de la rotura;

- energía de rotura por unidad de volumen.

Tensión máxima de flexión en el momento de la rotura

Se obtiene a partir del momento flector máximo y la sección rectangular media de cada pieza.

\section{Tensión máxima de cortante en el momento} de la rotura

La tensión tangencial se obtiene a partir del esfuerzo cortante y la sección media de cada pieza. La tensión tangencial se traduce en una tensión rasante que es máxima en el plano central de cada pieza y que, como consecuencia del comportamiento ortótropo de la madera, da lugar a la rotura por el plano de rasante. El plano
The span depends on the cross section of the groups of pieces. The $100 \times 150 \mathrm{~mm}$ pieces were tested with a span of $750 \mathrm{~mm}$, while the $100 \times 120 \mathrm{~mm}$ pieces were tested with a $600 \mathrm{~mm}$ span. Bending tests were conducted by applying the load at a constant velocity.

All the test results gave the following data for each piece:

- $\quad$ maximum bending stress at time of rupture;

- $\quad$ maximum shear stress at time of rupture;

- $\quad$ rupture energy per volume unit.

Maximum bending stress at time of rupture

This is obtained from the maximum bending moment and the average rectangular cross section of each piece.

\section{Maximum shear stress at time of rupture}

Shear stress is obtained from the shear force and the average cross section of each piece. It produces a maximum stress in the horizontal middle plane of the pieces, and due to the orthotropic behaviour of wood leads to breakage of the middle plane. The failure plane is affected by fissures because they represent a loss of 
de rasante está afectado por las fendas porque suponen una pérdida de sección resistente La tensión tangencial así obtenida se corrige en el plano medio de la viga en función de la pérdida de área debida a las fendas aplicando los índices de áreas. De esta forma se obtienen tres valores de tensión tangencial rasante: la nominal (calculada con la sección bruta) y dos valores corregidos (dividiendo la nominal por el índice de áreas $\mathrm{i}_{2} \mathrm{O}_{\mathrm{i}_{3}}$ ).

\section{Energía de rotura}

La energía o trabajo de rotura se obtiene como la mitad del producto de la carga de rotura $\left(P_{R}\right)$ por la flecha en el momento de la rotura $\left(\delta_{R}\right)$. Los valores de energía de rotura considerados en el análisis son valores unitarios que se obtienen dividiendo la energía total obtenida por el volumen de cada pieza, con el fin de evitar las diferencias de tamaño.

\subsection{Inventario de piezas}

Con la información de cada pieza se elabora una ficha y se construye una base de datos para su análisis que pueda ser implementada en el futuro con nuevas investigaciones (Figura 8). shear strength. In the middle plane of the beam the shear stress obtained was therefore corrected according to the loss of section due to the fissures, using the area index. Three values of shear stress were then obtained: the nominal value (calculated for the whole area) and two corrected values (dividing nominal value by $i_{2}$ or $i_{3}$ area indexes).

\section{Rupture energy}

Rupture energy is obtained as half the product of the failure load $\left(P_{R}\right)$ by the sag at the time of rupture $\left(\delta_{R}\right)$. In order to avoid differences in size, the rupture energy values considered in the analysis are obtained by dividing the total energy produced by the volume of each piece.

\subsection{Inventory of pieces}

A data card was developed and a database for analysis was constructed with all of the information obtained for each piece. This database can also be used with new research projects in the future (Figure 8 ).

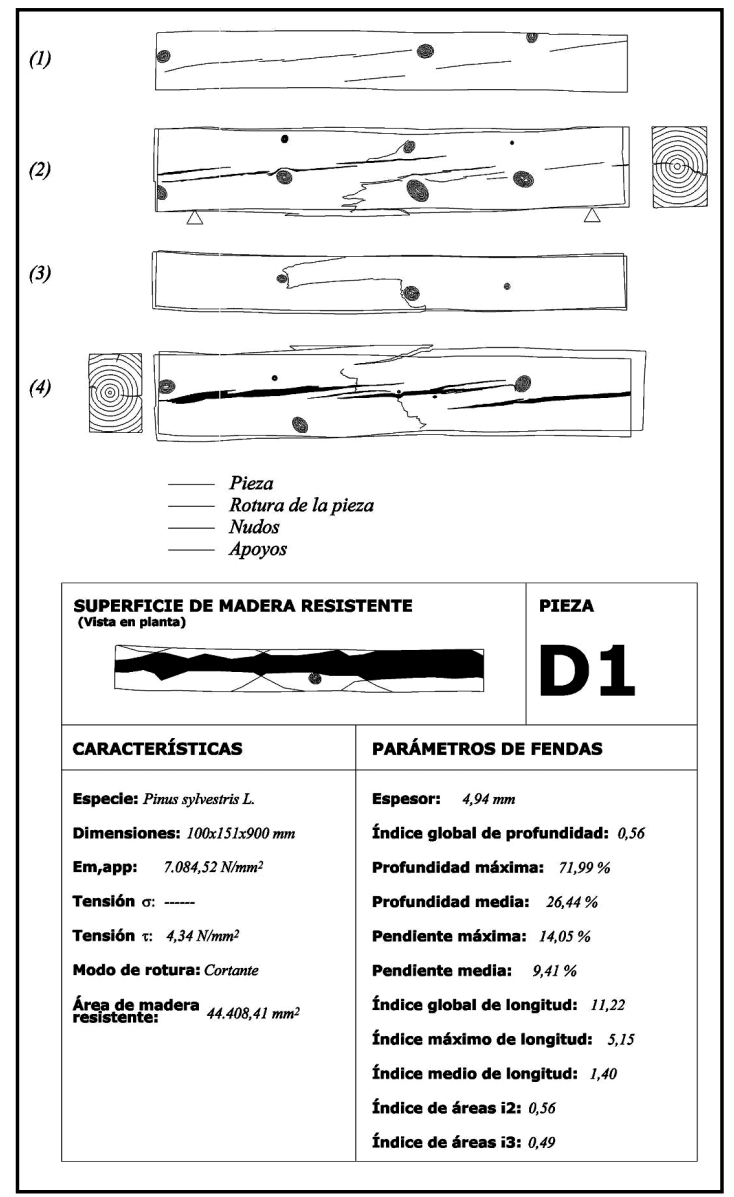

Figura 8. Ficha elaborada para cada pieza.

Figure 8. Data record for each piece. 


\section{RESULTADOS}

Las piezas estudiadas son de gran escuadría y antigüedad y presentan fendas de diferente espesor y profundidad, en ocasiones aparentemente grandes. Sin embargo, las especificaciones de la norma UNE 56544 (5) para la limitación de las fendas no rechazaría ninguna de las piezas. El índice de áreas $i_{3}$, definido anteriormente, alcanza en estas piezas un valor mínimo de 0,45 , mientras que las especificaciones de la norma conducen a unos valores admisibles de hasta 0,40 como mínimo (valores inferiores a 0,40 supondrían el rechazo por fendas).

Se han observado tres tipos de rotura en los ensayos: flexión con rotura de las fibras traccionadas (16 piezas), cortante mediante un fallo por tensiones rasantes en un plano horizontal ( 6 piezas) y una rotura mixta entre flexión y cortante en la que se observa un fallo combinado de ambos esfuerzos (5 piezas) (Figura 9). El porcentaje de fallos por cortante es de un $22 \%$ (6 piezas de un total de 27 ensayos válidos).

\section{RESULTS}

The material tested of old timber large cross section pieces has fissures of different thicknesses and depths which sometimes seem large. However, the UNE 56544 (5) standard specifications for the limitation of fissures would not reject any of these pieces. The " $i_{3}$ " area index, as defined above, reaches a minimum value of 0.45 in these pieces, while standard specifications lead to an admissible minimum value of up to 0.4 (as values below 0.40 would lead to rejection due to fissures).

Three types of failure have been observed in the tests: bending, failure of tension fibres (16 pieces), shear, horizontal plane rupture (6 pieces), and mixed shear and bending, with a combined failure of both (5 pieces) (Figure 9). The percentage of shear failures is $22 \%$ (6 pieces out of a total of 27 valid tests).

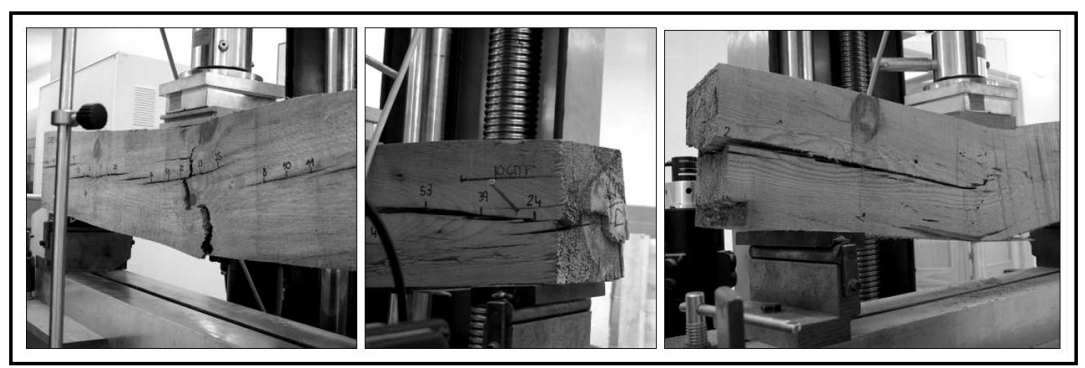

Figura 9. Tres modos de rotura: por flexión, por cortante y mixta. Figure 9. Three modes of failure: bending, shear and mixed.

\section{DISCUSIÓN}

La propiedad que mejor puede reflejar el comportamiento mecánico de las piezas es la energía unitaria en la rotura. Las tensiones de flexión y cortante en el momento de la rotura presentan el inconveniente de que están ligadas al modo de rotura (flexión o cortante), mientras que en la energía se integran la rigidez y la capacidad de carga de la pieza independientemente del modo de rotura. Expresar la energía por unidad de volumen permite unificar los resultados de los dos tamaños de piezas. En la Figura 10 se muestra el histograma de frecuencias de esta variable.

Se han analizado las correlaciones entre esta variable y los parámetros de evaluación de las fendas (espesor, inclinación, longitud, profundidad e índice de áreas). Los coeficientes de determinación obtenidos en todos los casos son inferiores a 0,10.

\section{DISCUSSION}

The property that may best reflect the mechanical behaviour of the pieces is unitary energy of rupture. Bending and shear stress at the time of fracture have the disadvantage of depending on the form of breakage (flexion or shear), while energy includes the stiffness and load capacity of the piece, no matter how breakage takes place. Energy per volume unit makes it possible to group the results of the two piece sizes. Figure 10 shows the frequency histogram of this variable.

The correlations between this variable and the fissure evaluation parameters (thickness, slope, length, depth and area indexes) were analyzed. The determination coefficients obtained in all cases are lesser than 0.10. 


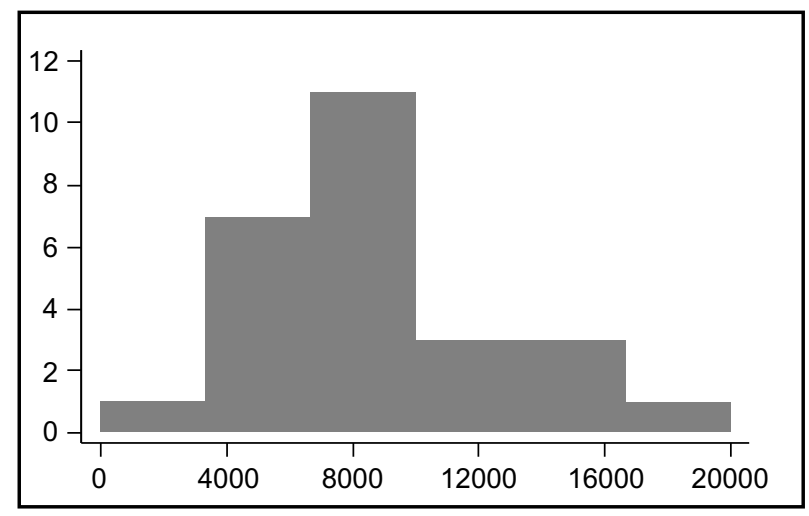

Figura 10. Histograma de frecuencias de la energía unitaria de rotura, en $\mathrm{J} / \mathrm{m}^{3}$.

Figure 10. Histogram of frequencies of the unitary energy of rupture, in $\mathrm{J} / \mathrm{m}^{3}$.

Por otro lado, para determinar si el tamaño de las fendas tiene alguna influencia en el comportamiento mecánico se ha realizado una clasificación de las piezas en función del índice de áreas $\left(i_{3}\right)$, obteniendo tres grupos con un número similar de piezas en cada uno:

- Clase 1: piezas con $\mathrm{i}_{3}<0,62$ (9 piezas) - fendas grandes.

- Clase 2: piezas con 0,62 $\leq \mathrm{i}_{3}<0,75$ (10 piezas) - fendas medias.

- Clase 3: piezas con $i_{3} \geq 0,75$ (7 piezas) - fendas pequeñas.

Después de realizar un análisis ANOVA (Figura 11) se observa que no existen diferencias significativas en la energía unitaria de rotura en función de la clase de tamaño de fendas.
On the other hand, to determine the influence of fissure size on mechanical behaviour, the pieces were classified according to area index $\left(i_{3}\right)$. As a result of this classification, three groups with a similar number of pieces in each were obtained:

- Class 1: pieces with $i_{3}<0.62$ (9 pieces) - Large fissures.

- Class 2: pieces with $0.62 \leq i_{3}<0.75$ (10 pieces) Medium fissures.

- Class 3: pieces with $i_{3} \geq 0.75$ (7 pieces) - Small fissures.

ANOVA analysis (Figure 11) shows that there are no significant differences in the rupture energy per volume unit, depending on fissure size class.

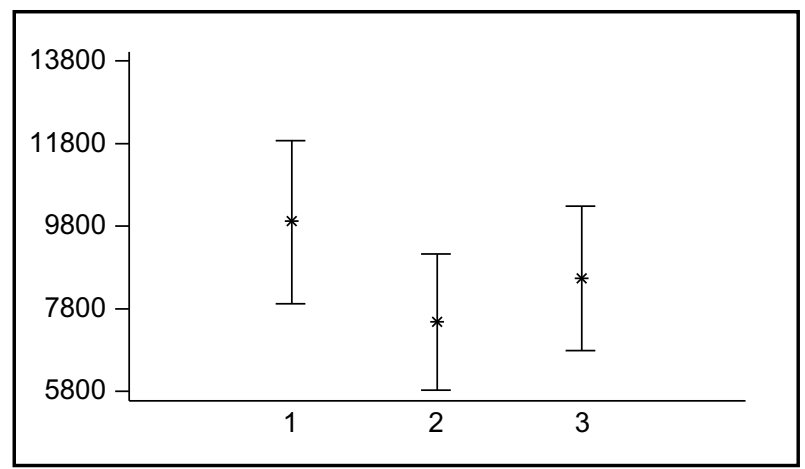

Figura 11. ANOVA de energía de rotura $(\mathrm{J} / \mathrm{m} 3)$ e índice de área i3 (clase 1,2 y 3 ).

Figure 11. ANOVA of energy of rupture (J/m3) and index of area i3 (class 1, 2 and 3 ).

\section{CONCLUSIONES}

Los criterios de fendas para la clasificación visual de acuerdo a la norma UNE 565444 (5) no producen ningún rechazo en las piezas estudiadas, en las que aparecen fendas de diferente magnitud.

\section{CONCLUSIONS}

The standard UNE 565444 (5) criterion for the visual classification of fissures does not reject the pieces studied, in which fissures of different sizes are found. 
Se han observado tres modos de rotura: por flexión (en el $59 \%$ de las piezas), por cortante $(22 \%)$ y mixta (19\%). Dentro de las piezas estudiadas y del tamaño de fendas observado, no se puede establecer una relación entre los modos de rotura y los parámetros de fendas, por lo que no es posible afirmar que las fendas sean determinantes del modo de rotura o, lo que es lo mismo, que la presencia de fendas grandes no son motivo para desencadenar fallos por cortante.

No se observan diferencias estadísticamente significativas entre el tamaño de las fendas y la capacidad de carga expresada mediante la energía de rotura por unidad de volumen. Aunque el número de datos analizado en este trabajo es reducido, los resultados apuntan a que la influencia de las fendas observadas sobre la capacidad resistente a flexión es prácticamente nula.

Respecto a la metodología se propone la energía de rotura por unidad de volumen como cuantificador de la capacidad mecánica, puesto que permite incluir la rigidez y la resistencia independientemente del modo de rotura. Los índices de áreas se proponen como parámetros de evaluación de las fendas más completos que las mediciones individuales de longitud y profundidad.

\section{AGRADECIMIENTOS}

Ministerio de Educación y Ciencia. Plan Nacional de Investigación Científica, Desarrollo e Innovación Tecnológica 2004-2007. Proy: BIA 2006 - 14272. Proyecto de investigación titulado: influencia de algunos defectos en las propiedades mecánicas de la madera de gran escuadría para uso estructural: fendas de secado y defectos de aserrado.
Three modes of rupture were observed: Bending (59\% of the pieces), shear (22\%) and mixed bending-shear (19\%). No connection can be found between the items studied and fissure size, so that it is not possible to establish a relationship between mode of rupture and fissure parameters. It is therefore not possible to affirm that fissure size determines how the breaking point is reached, nor, equally that large fissures do not always produce shear failures.

No statistically significant difference between fissure size and load capacity expressed by rupture energy per unit volume was found. Although the number of data analyzed in this study is low, the results suggest that the observed fissures have no influence on bending strength.

We propose rupture energy per volume unit as an estimator of load carrying capacity, as it includes stiffness and strength independently of rupture mode. Area indexes are proposed as more complete parameters for the evaluation of fissures than individual measurements of length and depth.

\section{ACKNOLEDGEMENTS}

Ministerio de Educación y Ciencia. Plan Nacional de Investigación Científica, Desarrollo e Innovación Tecnológica 2004-2007.Proy.: BIA 2006-14272. Research Project titled: Influencia de algunos defectos en las propiedades mecánicas de la madera de gran escuadría para uso estructural: fendas de secado y defectos de aserrado.

\section{BIBLIOGRAFÍA / BIBLIOGRAPHY}

(1) DIN 4074. Sortierung von Holz nach der Tragfähigkeit (Strength grading of wood).

(2) BS 4978. Visual strength grading of softwood. Specification for visual strength grading of softwood.

(3) NF B 52001. Règles d'utilisation du bois en structure.

(4) INSTA 142. Nordic visual stress grading rules for timber.

(5) UNE 56544. Clasificación visual de la madera aserrada para uso estructural: madera de coníferas (Visual stress grading of structural sawn timber: coniferous).

(6) Salomon. Charpente traditionelle: qualité et classement des bois de forte section. CTBA Info no 85 (2000), pp 9-14.

(7) UNE-EN 844-9. Madera aserrada y madera en rollo. Terminología. Parte 8: Términos relativos a las singularidades de la madera en rollo (Round and sawn timber. Terminology. Part 9: Terms relating to features of sawn timber.)

(8) Newlin, J. A.: "Shear in checked beams". Amer. Ry. Engin. Assoc. Bull. 364. 1001-1004, illus. (1934)

(9) Newlin, J. A.; Heck, G. E.; and March, H. W.: "New method of calculating longitudinal shear in checked wooden beams". Amer. Soc. Mech. Engin. Trans., 56: 739-744, illus. (1934)

(10) Barret, J. D. and Foschi, R. O.: "Shear strength of uniformly loaded dimension lumber". Canadian Journal of Civil Engineering, 4 , 86 (1976). doi:10.1139/177-009

(11) ASTM D245. Standard Practice for Establishing Structural Grades and Related Allowable Properties for Visually Graded Lumber. American Society for Testing and Materials. 1971. ASTM Standards, vol. 16. Philadelphia, PA. 
(12) Ido, H.; Nagao, H.; and Kato, H.: Evaluation of shear strength of timber by some non-destructive methods. Proceedings of the 14th International Symposium on Nondestructive Testing of Wood. University of Applied Sciences Eberswalde, Germany. Hannover may 2-4, 2005 (2005), pp. 415-420.

(13) Íñiguez, G.: Clasificación mediante técnicas no destructivas y evaluación de las propiedades mecánicas de la madera aserrada de coníferas de gran escuadría para uso estructural (Grading by non destructive techniques and assessment of the mechanical properties of large cross section coniferous sawn timber for structural use). Doctoral Thesis. Universidad Politécnica de Madrid, ETS de Ingenieros de Montes. 223 p (2007). PDF file: http://oa.upm.es/415.

(14) Pedrotti, P.; Paganini, F. and Del Senno, M.: "Longitudinal boring of beams". Xylon International, jul-aug (2000), pp 72-75.

(15) Klöck, W.: "Statistical analysis of the shear strength of glued laminated timber based on full-size flexure tests". Otto-Graf-Journal, vol. 16 (2005), pp. 225-243.

(16) Aicher, S.; Hill-Langer, G. and Ringger, T.: "Non-Destructive detection of longitudinal cracks in glulam beams". Otto-Graf-Journal, vol. 13, (2002) pp. 165-181.

(17) Esteban, M.: Determinación de la capacidad resistente de la madera estructural de gran escuadría y su aplicación en estructuras existentes de madera de conifera (Determination of the load carrying capacity of large cross section structural coniferous timber on existing structures). Doctoral Thesis. Universidad Politécnica de Madrid, ETS de Ingenieros de Montes. 365 p. (2003) PDF file: http://oa.upm.es/1404.

(18) Arriaga, F.; Esteban, M. y Relea, E.: "Evaluación de la capacidad portante de piezas de gruesa escuadría de madera de conífera en estructuras existentes" (Evaluation of the load carrying capacity of large cross section coniferous timber in standing structures). Mater. Construcc., vol. 55, no 280 (2005), pp. 43-52. doi:10.3989/mc.2005.v55.i280.205

(19) Mateo, R.: "Análisis de la influencia de las fendas en la capacidad resistente de piezas de madera" (Analysis of influence of fissures in load carrying capacity of timber pieces). Proyecto Fin de Carrera. ETSI Montes. Universidad Politécnica de Madrid (2005).

(20) Arriaga, F.; "Esteban, M.; Argüelles, A.; Bobadilla, I. e Íñiguez, G.: Efecto de las gemas en la resistencia a flexión de piezas enterizas de madera" (The effect of wanes on the bending strength of solid timber beams. Materiales de Construcción. Mater Construcc., vol. 57, n० 288 (2007), pp. 61-76.

(21) UNE-EN 408. Estructuras de madera. Madera aserrada y madera laminada encolada para uso estructural. Determinación de algunas propiedades físicas y mecánicas (Timber structures. Sawn timber and glued laminated timber for structural use. Determination of some physical and mechanical properties). 